\title{
Reflection on the Complexity of Mathematical Objects in the Initial Training of Teachers
}

\author{
Eulalia Calle \\ Universidad de Cuenca \\ Adriana Breda \\ Universitat de Barcelona \\ Vicenç Font \\ Universitat de Barcelona
}

This work aims to know the perception of future mathematics teachers about the complexity of mathematical objects and their possible application in teaching practice, in order to improve the teaching and learning of mathematics in Basic General Education $(G B S)$ and the Unified General Baccalaureate (BGU). For this, 19 future professors were asked about the different meanings of some mathematical objects, and they were proposed to raise contextualized problems in which a certain meaning had to be applied in their resolution. The results show that encouraging reflection on the complexity of mathematical objects in the initial training of teachers and their relationship with the design of contextualized problems affects their way of understanding mathematical competence

Keywords: initial teacher training, complexity of mathematical objects, contextualized problems

\section{INTRODUCTION}

One of the areas of study of Mathematics Education is initial teacher training, due to the important role of the mathematics teacher in the development of instructional processes. In order to improve the training of future teachers and, as a consequence, to enhance the teaching and learning processes of mathematics, teacher training courses are emphasizing the application, in the training courses, of theoretical and methodological contributions related both to the results of research in the area of Didactics of Mathematics (DM), and to some current trends concerning the teaching of mathematics (Problem Solving, use of ICT, active learning, etc.) arising from these results.

A fundamental aspect to work on in the initial training of mathematics teachers - as pointed out by different research (Font, 2007; Pino-Fan, Godino, \& Font, 2011; Pino-Fan, et al, 2018; Rondero \& Font, 2015 ) - is the reflection about the different meanings of mathematical objects and their applications in the resolution of contextualized tasks.

To a greater or lesser extent, the complexity problem associated with the mathematical object, and the link between the components in which this complexity explodes, is present in almost all the emerging theoretical frameworks in the area of Mathematics Education. In this article we will take the Onto-semiotic 
Approach to Mathematical Cognition and Instruction (OSA, from now on) (Godino, Batanero, \& Font, $2007 \& 2019$ ) as a theoretical reference. Working on the different meanings of a mathematical object is an aspect proposed in the OSA, where it is suggested to work on the complexity of mathematical objects through their multiple meanings.

Understanding the complexity in terms of a plurality of meanings is a result of the pragmatic view regarding meaning that is assumed in the OSA. From a pragmatic point of view, the meaning of a mathematical object is understood as the set of practices in which this object is involved in a determinant way (or not). In other words, it implies having practices regarding the field of experience that the object involves. When the meaning of a mathematical object is defined in terms of practices, as proposed in pragmatism, it appears that the meaning of a mathematical object is linked to other meanings and to other objects, since in practices this object is involved together with other mathematical objects. This fact makes it possible to make a distinction between two terms that are difficult to separate, we refer to the terms sense and meaning. Indeed, given that the object can be related to one or other objects depending on the context, the type of notation, etc. in order to give rise to different practices, we can understand sense as a partial meaning, that is, as a subset (sense) of the system of practices in which the object is determinant (meaning).

The meaning of a mathematical object understood as a system of practices can be divided into different kinds of more specific practices that are used in a specific context and with a specific type of notation, producing a specific sense. Each context helps to generate sense (allows the generation of a subset of practices), but does not generate all senses.

A mathematical object, which has been originated as an emergent of the system of practices that allows to solve a certain field of problems, with the passage of time is framed in different research programs. Each new research program allows solving new types of problems, applying new procedures, relating the object (and therefore defining) in a different way, using new representations, and so on. In this way, with the passage of time, new subsets of practices (senses) appear and extend the meaning of the object.

This work aims to know the perception of future mathematics teachers about the complexity of mathematical objects and their possible application in teaching practice, in order to improve the teaching and learning of mathematics in Basic General Education and the Unified General Baccalaureate.

The structure of the article is as follows. First, a brief explanation of some of the OSA constructs is provided, detailing the theoretical tool used in this research, followed by a description of the qualitative methodology followed, an analysis of the work of the participants in this proposal, and a discussion of the results.

\section{THEORETICAL FRAMEWORK}

In the theoretical framework we briefly explain the CCDM model of the OSA, going deeper into the representative sample component of the mathematical object complexity to be taught of the epistemic suitability criteria.

\section{The CCDM Model and Didactic Suitability}

The model of mathematics teacher competences and knowledge (CCDM model) is based on OSA constructs (Godino, Batanero, \& Font, 2007; Godino, Batanero, \& Font, 2019) and articulates several categories of mathematics teachers' knowledge and competences considered necessary for an ideal mathematics teaching (Godino, Giacomone, Batanero, \& Font, 2017). This theoretical model highlights the analysis of didactic suitability, as a competence for global reflection on teaching practice, its assessment and progressive improvement (Giacomone, Godino, \& Beltrán, 2018); therefore, it answers what criteria to follow in the design of task sequences to develop and assess students' mathematical competence and what changes to make in order to achieve higher learning goals. This notion is categorized into the following partial criteria of didactic suitability (Font, Planas \& Godino, 2010):

$\checkmark$ Epistemic suitability: refers to the degree of representativeness and interconnectedness of the implemented (or intended) institutional meanings in relation to a reference meaning. Tasks or 
problem-situations are a critical component of this dimension, and should involve a variety of mathematical objects and processes.

$\checkmark$ Ecological suitability: degree to which the study process is in line with the educational project of the institution, the school and society, and with the conditions of the environment in which it is developed.

$\checkmark$ Cognitive suitability: degree to which intended and implemented meanings are in the area of potential learner development, as well as the proximity of achieved personal meanings to intended/implemented meanings.

$\checkmark$ Affective suitability: degree of involvement (interests, emotions, attitudes and beliefs) of the students during the study process.

$\checkmark$ Interactional suitability: degree to which didactic configurations and classroom discourse allow, on the one hand, to identify potential semiotic conflicts (that can be detected in advance), and on the other hand, to resolve conflicts that occur during the instructional process.

$\checkmark$ Means suitability: degree of availability and adequacy of the material and time resources necessary for the development of the teaching-learning process.

According to Breda and Lima (2016) and Breda, Pino-Fan and Font (2017), a system of components and indicators is provided as a guide for the analysis and assessment of didactic suitability, which is designed for an instructional process at any educational stage.

\section{Epistemic Suitability and the Complexity of Mathematical Objects}

The components and indicators of the didactic suitability criteria have been developed taking into consideration the trends, principles and results of research in the area of Didactics of Mathematics. Particularly, for epistemic suitability, a fundamental principle of EOS has been taken into account which, with the nuances specific to each approach, is (or can be) assumed by other theoretical approaches in the area. We refer to the principle that can be stated as follows: mathematical objects emerge from practices, which entails their complexity (Font, Godino, \& Gallardo, 2013; Rondero \& Font, 2015). From this principle a component (representativeness) is obtained, whose objective is to take into account, as far as possible, such complexity in the design and redesign of didactic sequences (Pino-Fan, Castro, Godino, \& Font, 2013).

The Representativeness component of the mathematical object complexity (understood as plurality of partial meanings), refers to the degree of representativeness and interconnectedness of the implemented (or intended) institutional meanings regarding a reference meaning (Giacomone, Godino, \& Beltrán-Pelliecer, 2018). Each of these meanings allows solving different types of problems, so if you want to apply the mathematical object to solve different problems (mathematical competence) it is necessary to teach a representative sample of partial meanings (Font, Breda, \& Seckel, 2017).

The following table (Font, Breda, \& Seckel, 2017), explains in detail, the indicators of the Representativeness component of the epistemic suitability criteria. 
TABLE 1

THE REPRESENTATIVENESS COMPONENT AND ITS INDICATORS

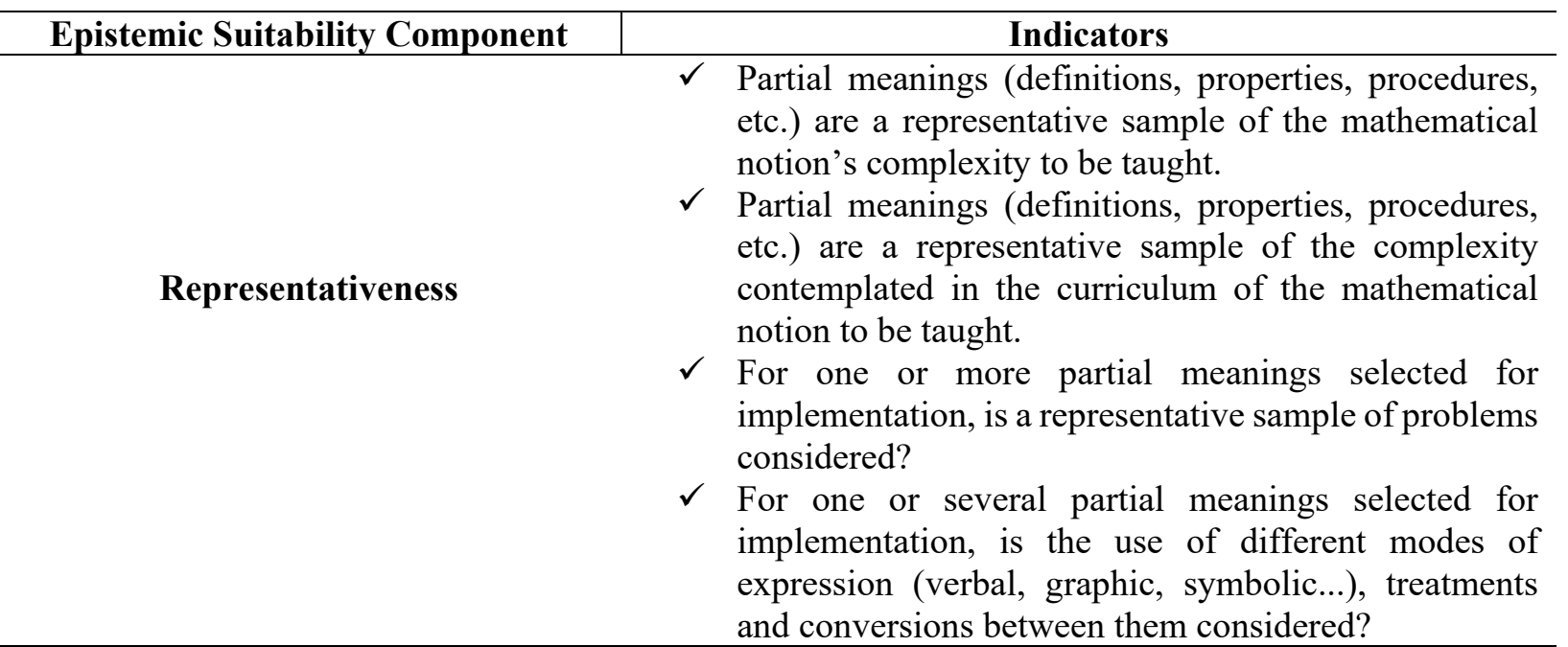

Source: Font, Breda, and Seckel (2017).

\section{Investigations Regarding the Complexity of Different Mathematical Objects}

Different researches have been carried out in order to deepen the complexity of different mathematical objects: natural numbers (Godino, Font, Wilhelmi, \& Arrieche, 2009), arithmetic mean (Rondero \& Font, 2015), limit (Contreras, García, \& Font, 2012), optimization (Balcaza, Contreras, \& Font, 2017), proportionality (Godino, Beltrán-Pellicer, Burgos, \& Giacomone, 2017; Burgos, Castillo, Beltrán-Pellicer \& Godino, 2020), Tales' Theorem (Font, Breda, \& Seckel, 2017), derivative and antiderivative, as well as students' understanding of such complexity (Pino-Fan, Godino, \& Font, 2011; Pino-Fan, Castro, Godino, \& Font, 2013; Pino-Fan, Font, Gordillo, Larios, \& Breda, 2018; Pino-Fan, Godino, \& Font, 2018), inequation (Monje, Seckel, \& Breda, 2018).

For the mathematical object "derivative", Pino-Fan, Godino and Font (2011) characterize the complexity of the mathematical object by nine primary object configurations: 1) tangent in Greek mathematics; 2) variation in the Middle Ages; 3) algebraic methods for finding tangents; 4) kinematic conceptions for tracing tangents; 5) intuitive ideas of limit for calculating maxima and minima; 6) infinitesimal methods in calculating tangents; 7) Methodus fluxionum; 8) calculation of differences; and, 9) derivative as limit. In Pino-Fan, Castro, Godino and Font (2013) these nine configurations are used for the reconstruction of the global meaning of the derivative, which is used to assess the representativeness of the intended meaning in the Mexican high school curriculum (from the configurations of primary objects activated in the mathematical practices proposed both in the Curriculum and in the textbooks of that level).

The complexity characterization of the derivative made in Pino-Fan, Godino and Font (2011) facilitates having elements to design questionnaires to identify the understanding of students, future teachers or inservice teachers about the derivative. In Pino-Fan, Godino and Font and (2018) a questionnaire was designed in order to determine prospective teachers' understanding about the derivative in which tasks that activate the different partial meanings of the derivative characterized in Pino-Fan, Godino and Font (2011) were included.

In Gordillo and Pino-Fan (2016) the antiderivative complexity is defined by four primary object configurations related to four basic problems: a) the geometric problem of the tangents of a curve and the quadrature of the curve; b) the problem of the relation fluxions - fluents; c) the problem concerning the relation of differentials and summations; and d) the problem of the identification of elementary functions. The characterization of such complexity allows us to have elements available to design questionnaires that enable us to identify the understanding of students, future teachers or in-service teachers about the antiderivative. In Gordillo, Pino-Fan, Font, and Ponce (2018) and in Pino-Fan, Font, Gordillo, Larios, and 
Breda (2018) a questionnaire was designed to determine university students' understanding about the antiderivative in which tasks activating the different partial meanings of the antiderivative characterized in Gordillo and Pino (2016) were included.

Monje, Seckel and Breda (2018), by means of a comparative analysis between the complexity of the mathematical object, inequation with the national curriculum and the school texts granted by the Ministry of Education of Chile, concluded that the treatment given to the mathematical object under study (inequalities) does not consider all the necessary components for the teaching of the inequation from its complexity, in particular, it was observed that both the curriculum and the school texts leave out, in particular, quadratic inequalities and inequalities with absolute value.

These investigations concluded that teachers should take into account the complexity of the mathematical objects they teach in order to obtain more effective teaching, which led the authors of this article to become interested in how to incorporate the problem of the mathematical object complexity in teacher training.

\section{OBJECTIVE}

Understanding the perception that future mathematics teachers have about the importance of considering the complexity of mathematical objects in their teaching practice.

\section{METHODOLOGY}

In this section, we provide the study context (institution involved, research participants, etc.) and the qualitative methodology used to analyze the participants' responses.

\section{Study Context}

Nineteen future mathematics teachers who are studying the second semester of the Advanced Algebra course of the Experimental Sciences Pedagogy Career: Mathematics and Physics, at the University of Cuenca, participated in the study.

\section{Research Study Phases}

In the first phase, the students jointly with the teacher agreed on a series of mathematical objects, of which they would deepen about their complexity. In the second phase, with the objects assigned and the groups organized, they were provided with literature related to the object on which they had to reflect. In a third phase, the group had to ask itself questions such as what are the partial meanings of the mathematical object worked on by the students and what representations could be given to the partial meanings of these mathematical objects. In a fourth phase, they were also asked to propose problems for each meaning. In the fifth phase, each group reported its reflections to the entire group. In a sixth phase, the whole group solved the tasks that had been proposed in each small group. Finally, the students discussed the results obtained, analyzing their application and generalization, through conclusions and recommendations to take into account the mathematical objects complexity in the instructional processes.

\section{RESULTS}

The students participating in this study were organized into five groups of four or five students, sharing their proposals through a debate of ideas and presenting the following information as a result: 
TABLE 2

WORK DONE BY STUDENTS PARTICIPATING IN THE PROPOSAL. GROUP NO. 1

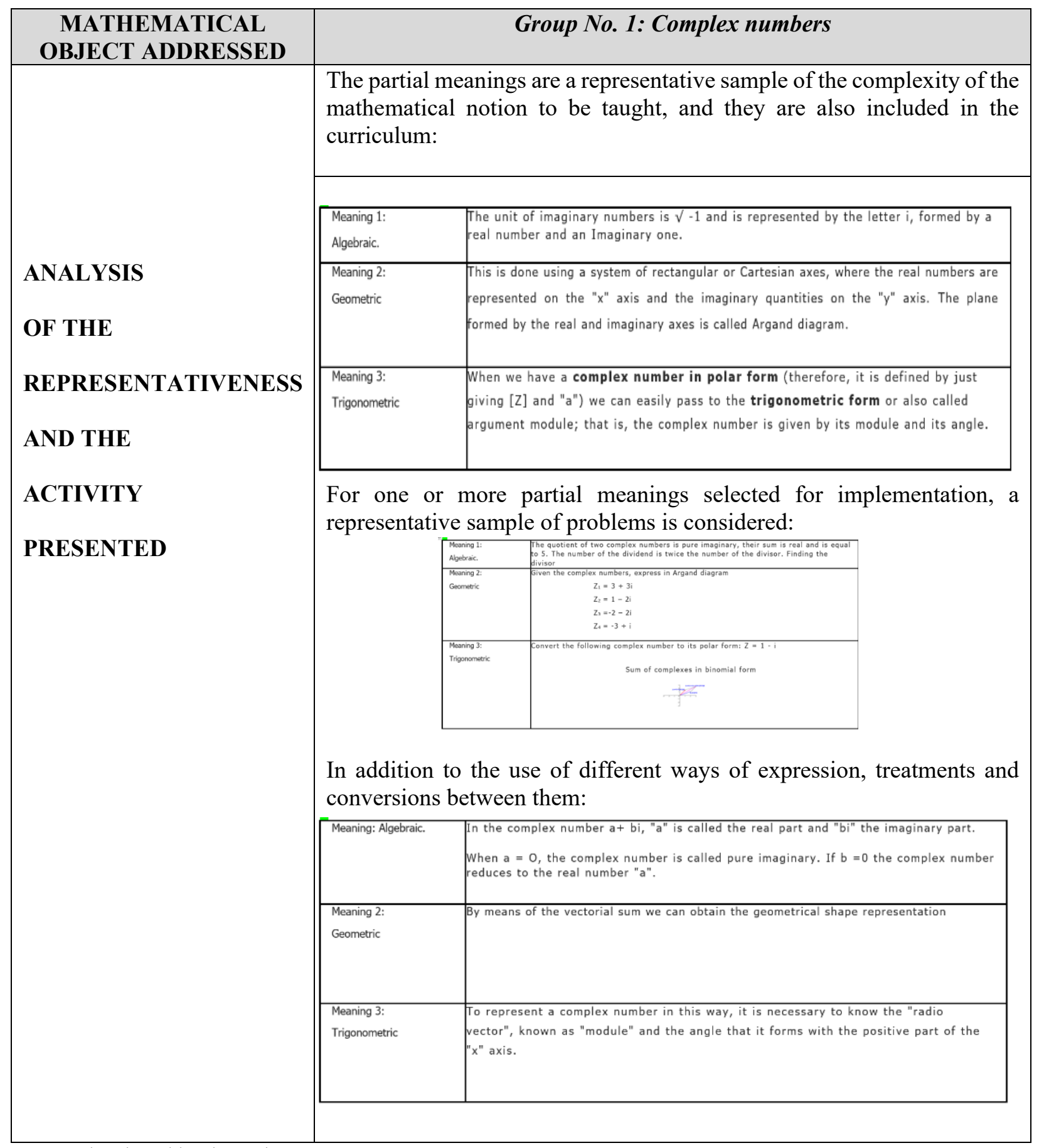

Source: developed by the authors.

Analyzing the activity performed by group No. 1, it can be evidenced that they comply with the representativeness of the epistemic suitability criteria, through their three partial meanings: algebraic, geometric and trigonometric; in addition to a representative sample of problems and the use of different ways of expression, such as verbal, graphic, symbolic and others. 
After the discussion of this work, the presenters applied the following task, obtaining as a result that, out of the 15 participating students, 12 answered correctly to the questions posed in the task and only three students made minimal errors, as stated by the evaluators of group 1: "They correctly identified the algebraic meaning, but had a small error because they did not distinguish the properties of complex numbers".

FIGURE 1

TEST APPLIED BY GROUP NO. 1.

\begin{tabular}{|c|}
\hline University of Cuenca \\
\hline Pedagogy of Experimental Sciences \\
\hline Complex Numbers \\
\hline $\mathbf{1}$ Calculate $\mathbf{E}=\frac{\boldsymbol{x}+\boldsymbol{y}}{\boldsymbol{x}-\boldsymbol{y}^{3}} \quad$ Date: $07 / 01 / 2019$ \\
\hline $\begin{array}{l}\text { If it is fulfilled that }(1+i) 2+(1+i) 4+(1+i) 6+(1+i) 8=x+y i \\
\text { What is the meaning of complex number that you have used? }\end{array}$ \\
\hline
\end{tabular}

Source: Developed by the Authors

The activity performed by the following group is detailed below:

TABLE 3

WORK DONE BY STUDENTS PARTICIPATING IN THE PROPOSAL. GROUP NO. 2

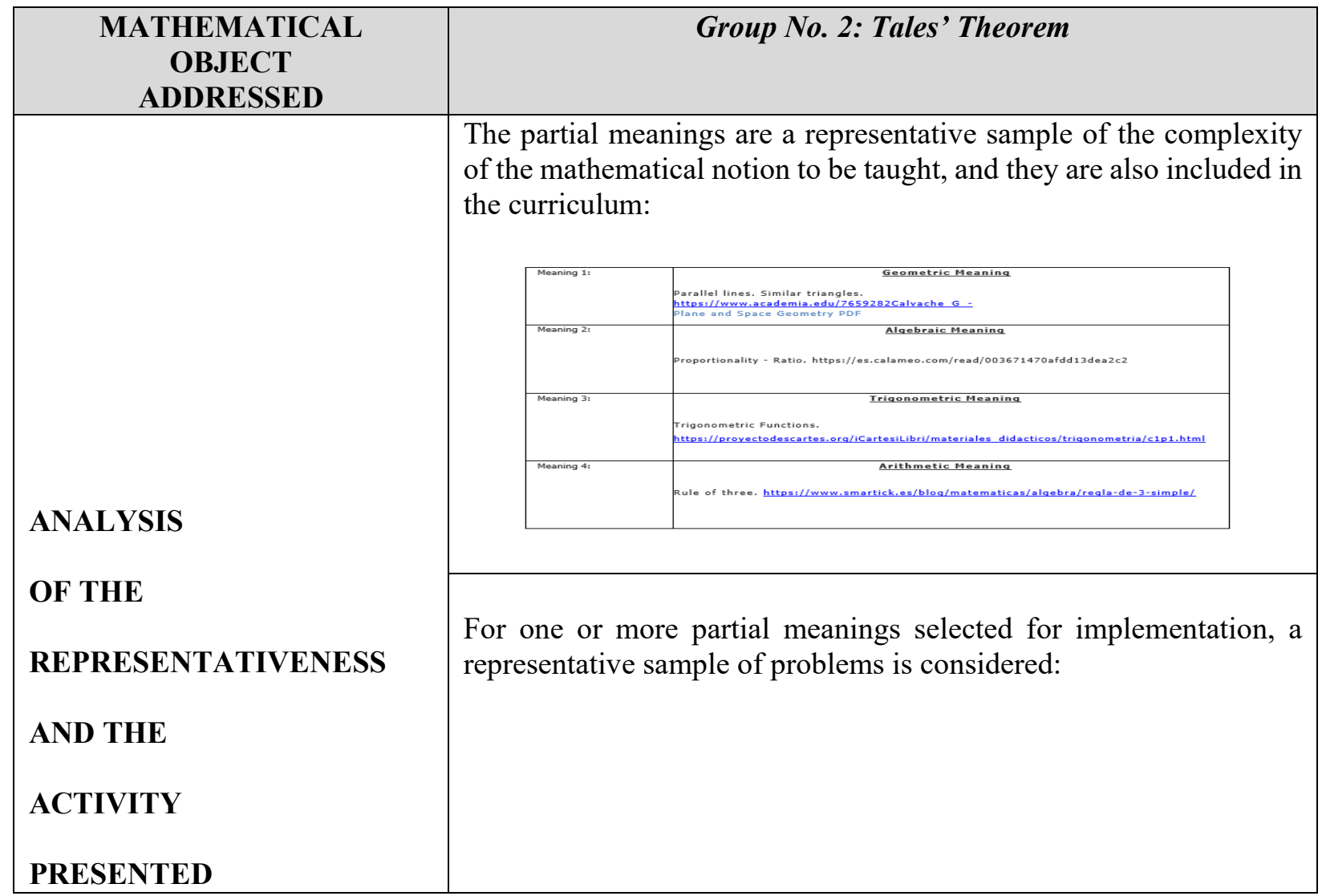




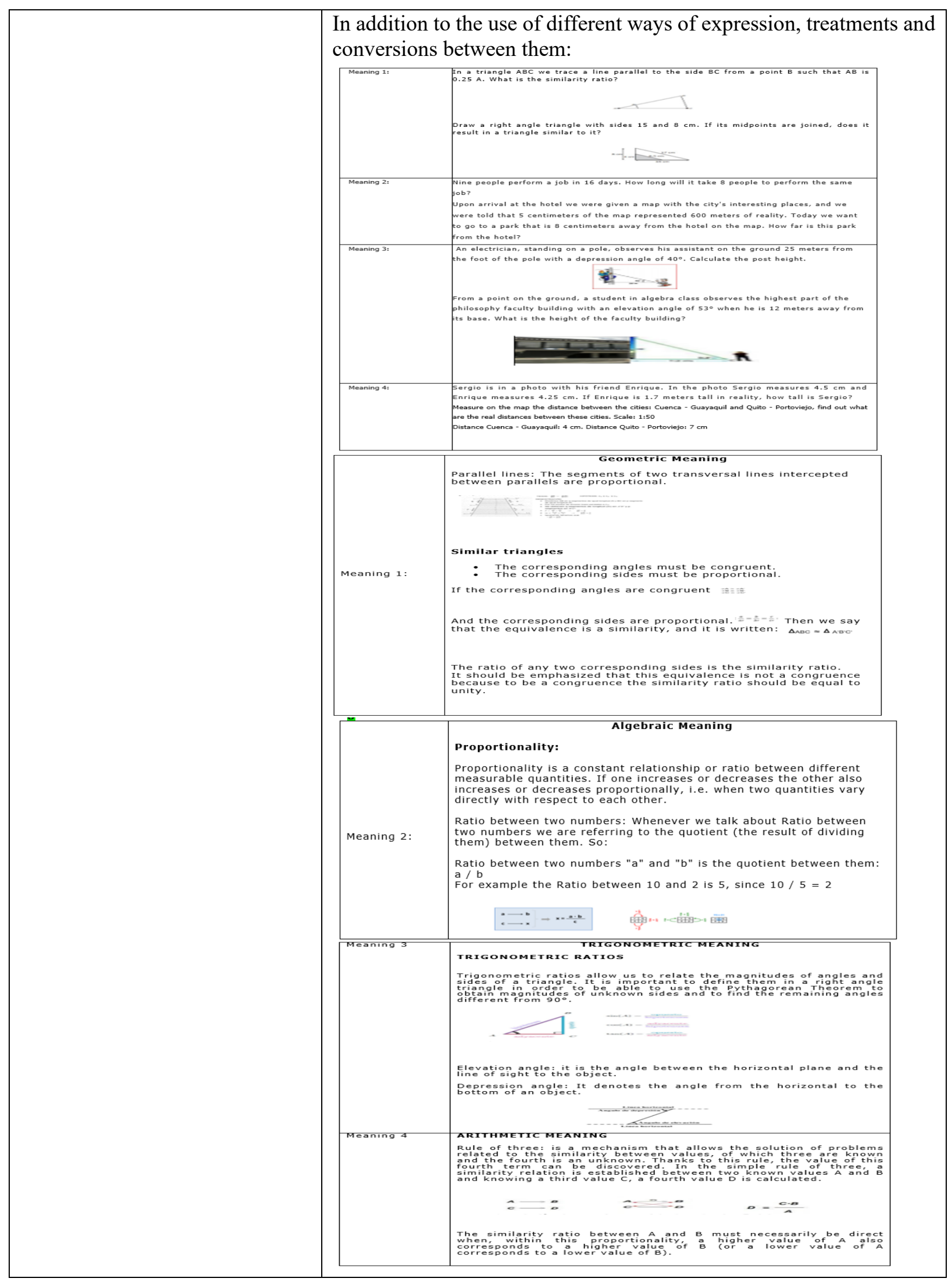

Source: developed by the authors.

204 Journal of Higher Education Theory and Practice Vol. 21(13) 2021 
Similar to the previous case, it can be seen that the group No. 2, complies with the representativeness component of the epistemic suitability criteria, where it is expressed in four partial meanings: algebraic, arithmetic, geometric and trigonometric.

When applying the evaluation, they obtain as a result that, out of the 14 participating students, seven demonstrate a good application and connection of meanings with the problems posed, while the others, having an error, in the words of the group: "they recognize and apply the connection of the meanings with the problems posed".

FIGURE 2

TEST APPLIED BY GROUP NO. 2

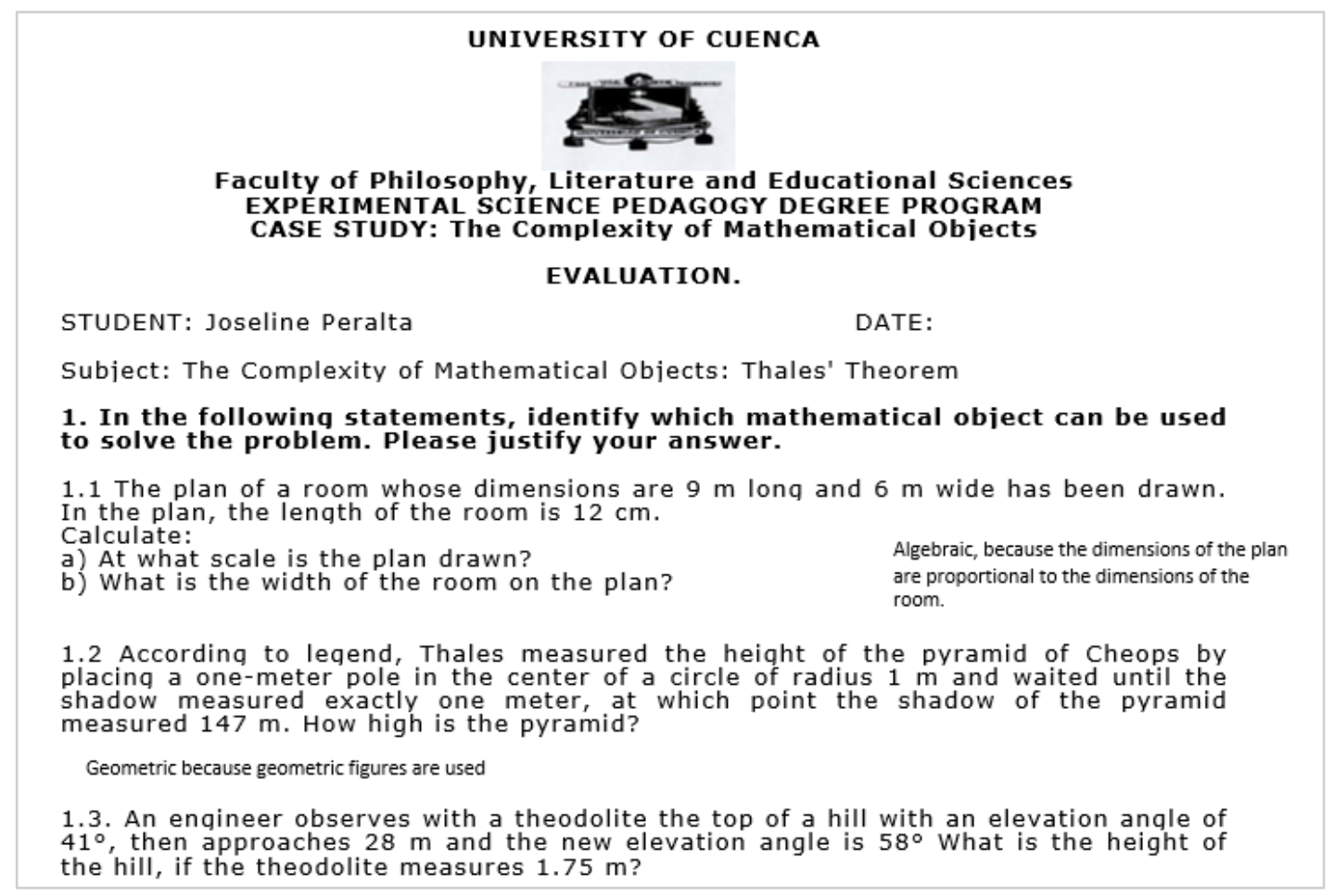

Source: Developed by the Authors

The detail of the next group's activity is:

\section{TABLE 4}

WORK DONE BY STUDENTS PARTICIPATING IN THE PROPOSAL. GROUP NO. 3

\begin{tabular}{|c|c|c|}
\hline \multirow{4}{*}{$\begin{array}{l}\text { MATHEMATICAL } \\
\text { OBJECT ADDRESSED } \\
\end{array}$} & \multicolumn{2}{|r|}{ Group No. 3: Equations } \\
\hline & \multicolumn{2}{|c|}{$\begin{array}{l}\text { The partial meanings are a representative sample of the complexity of the } \\
\text { mathematical notion to be taught, and they are also included in the } \\
\text { curriculum: }\end{array}$} \\
\hline & $\begin{array}{l}\text { Meaning 1: } \\
\text { ALGEBRAIC }\end{array}$ & 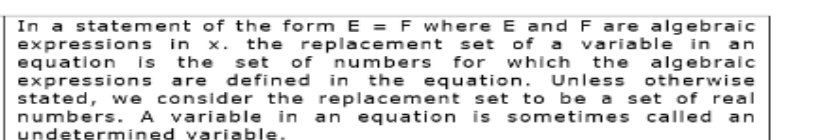 \\
\hline & $\begin{array}{l}\text { Meaning 2: } \\
\text { GEOMETRC } \\
\text { Meaning } 3: \\
\text { TRIGONOMETRIC }\end{array}$ & 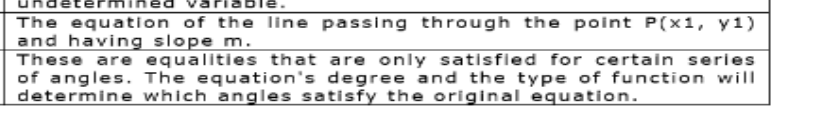 \\
\hline
\end{tabular}




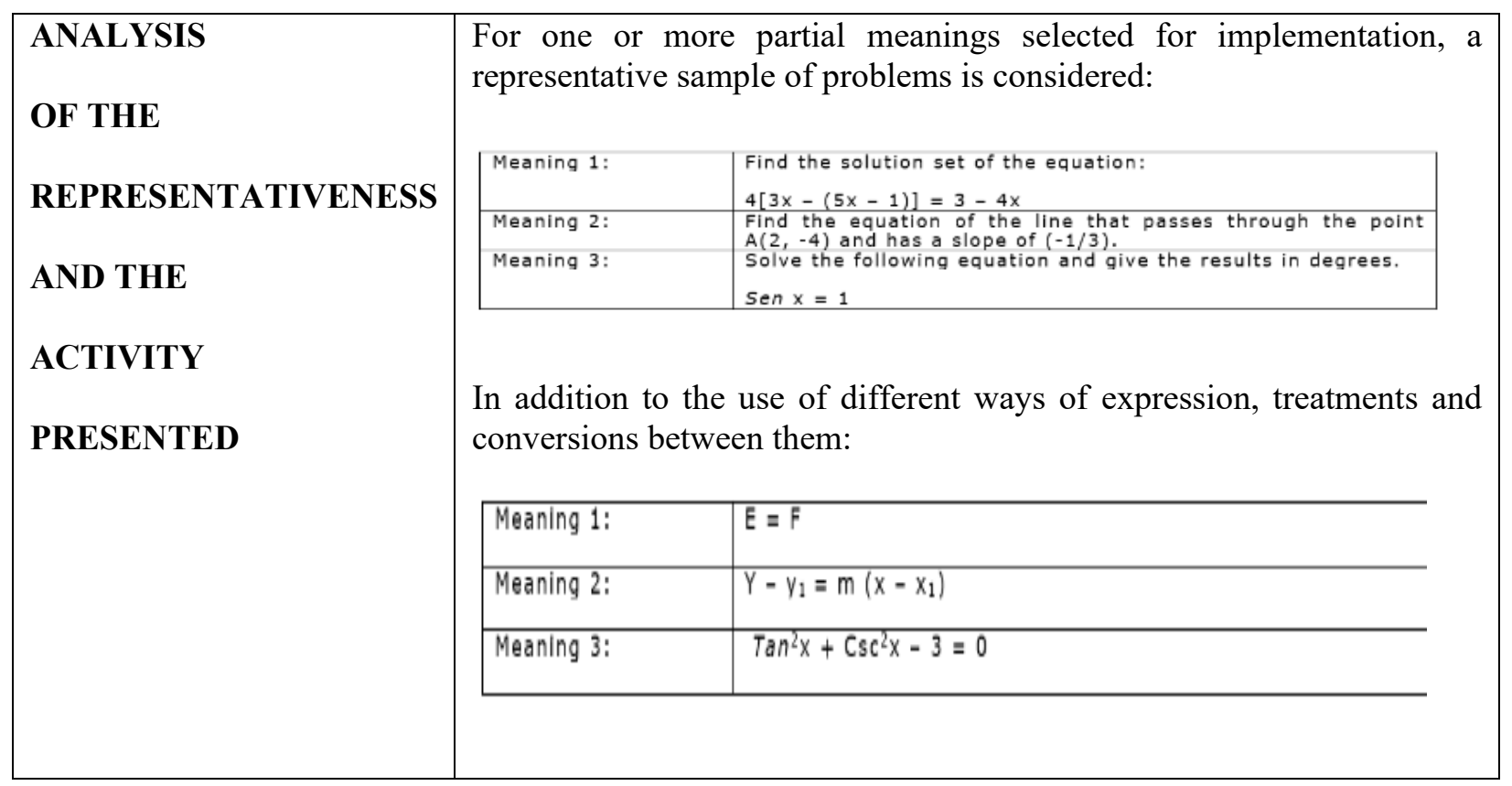

Source: developed by the authors.

Group No. 3 works on the representativeness of the mathematical object "equations" in a very elementary way and analyzes the evaluation of six of their classmates, where four of them answered the evaluation correctly and only two could not relate the meanings with the proposed problems.

It can be concluded that, in spite of presenting a rather simple work, the presenters' understanding regarding the mathematical object "equations" complexity is visible.

\section{FIGURE 3}

\section{TEST APPLIED BY GROUP NO. 3.}

Problem 1: Find all the solutions of the following equation:
Sen $x+\cos x=\sqrt{ } 2$
a. Relate it to a type of meaning.
b. Write down why you related to with that meaning.
Problem 2: "Passerby, this is the tomb of Diophantus: this is the one who with this
surprising distribution tells you the number of years he lived. His childhood occupied
the sixth part of his life; then during the twelfth part his cheek was covered with the
first face hair He spent yet another seventh part of his life before he married, and
five years later, he had a precious child who, having reached half his father's age,
perished of an unfortunate death. His father had to survive him, mourning him, for
four years. From all this we can deduce his age".
Relate to one type of meaning.

Source: Developed by the Authors

The following group presents its work, according to the following details: 
TABLE 5

WORK DONE BY STUDENTS PARTICIPATING IN THE PROPOSAL. GROUP NO. 4

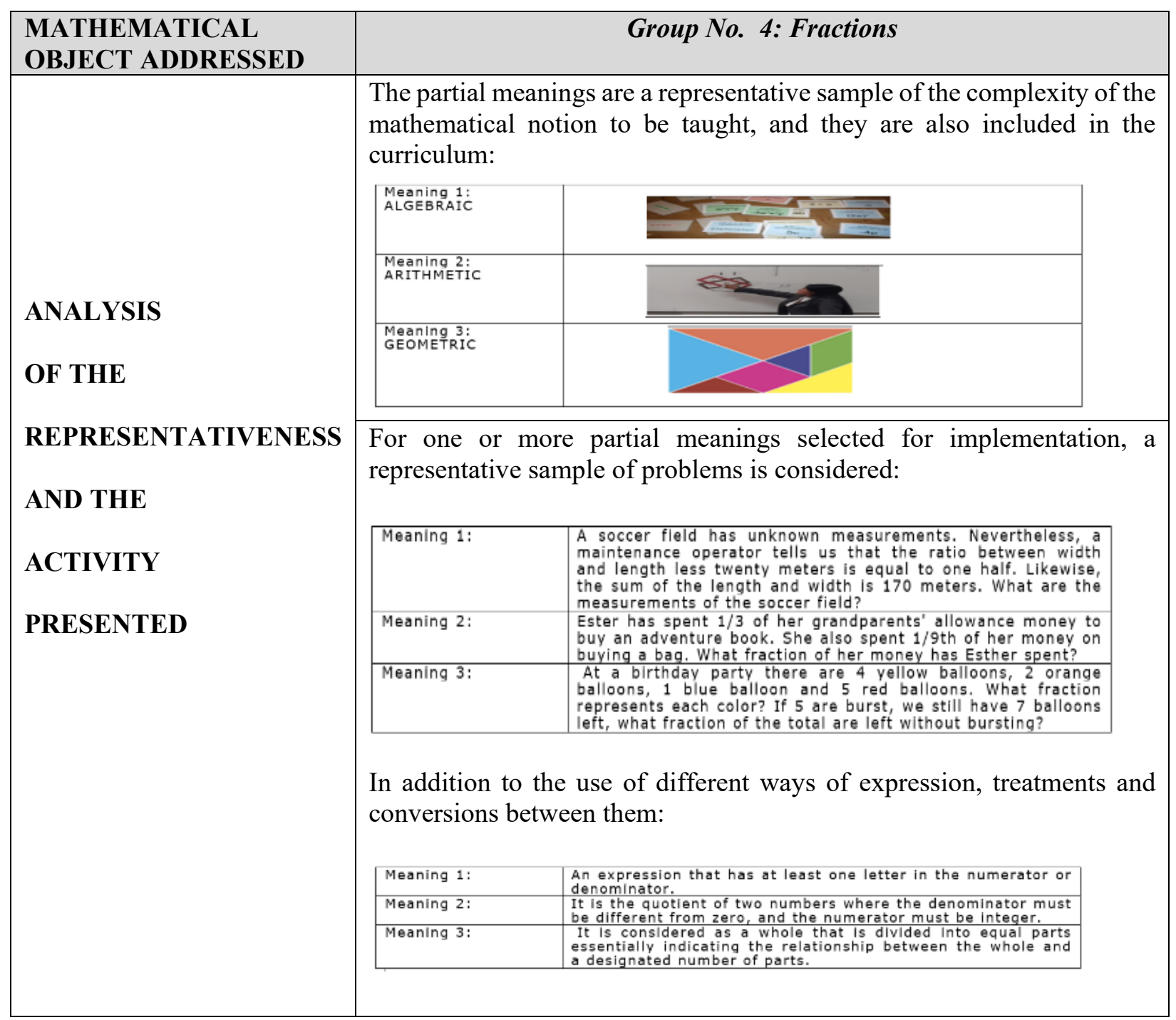

Source: developed by the authors.

Group No. 4 shows compliance with the representativeness component, through algebraic, geometric and trigonometric meaning. On the other hand, in the evaluation applied to 15 students, 11 of them "Apply correctly the algebraic, geometric or trigonometric meanings, as appropriate"; while the others do not justify their given answers.

The next group shares its proposal in the following way: 
FIGURE 4

TEST APPLIED BY GROUP NO. 4

\section{EVALUATION OF THE PROPOSAL}

The following table shows the results obtained from the evaluation applied to our classmates, the purpose of which is to demonstrate whether the understanding of the meanings of the mathematical object Fractions is achieved. Problem 1: Solve:

$$
\begin{gathered}
E=\frac{a-b}{(b+c-a)(b-c-a)}+\frac{b-c}{(c+a-b)(c-a-b)} \\
+\frac{c-a}{(a+b-c)(a-b-c)}
\end{gathered}
$$

\section{Problem 2:}

Determine to which meaning it belongs. Please justify your answer.

TABLE 6

WORK DONE BY STUDENTS PARTICIPATING IN THE PROPOSAL. GROUP NO. 5

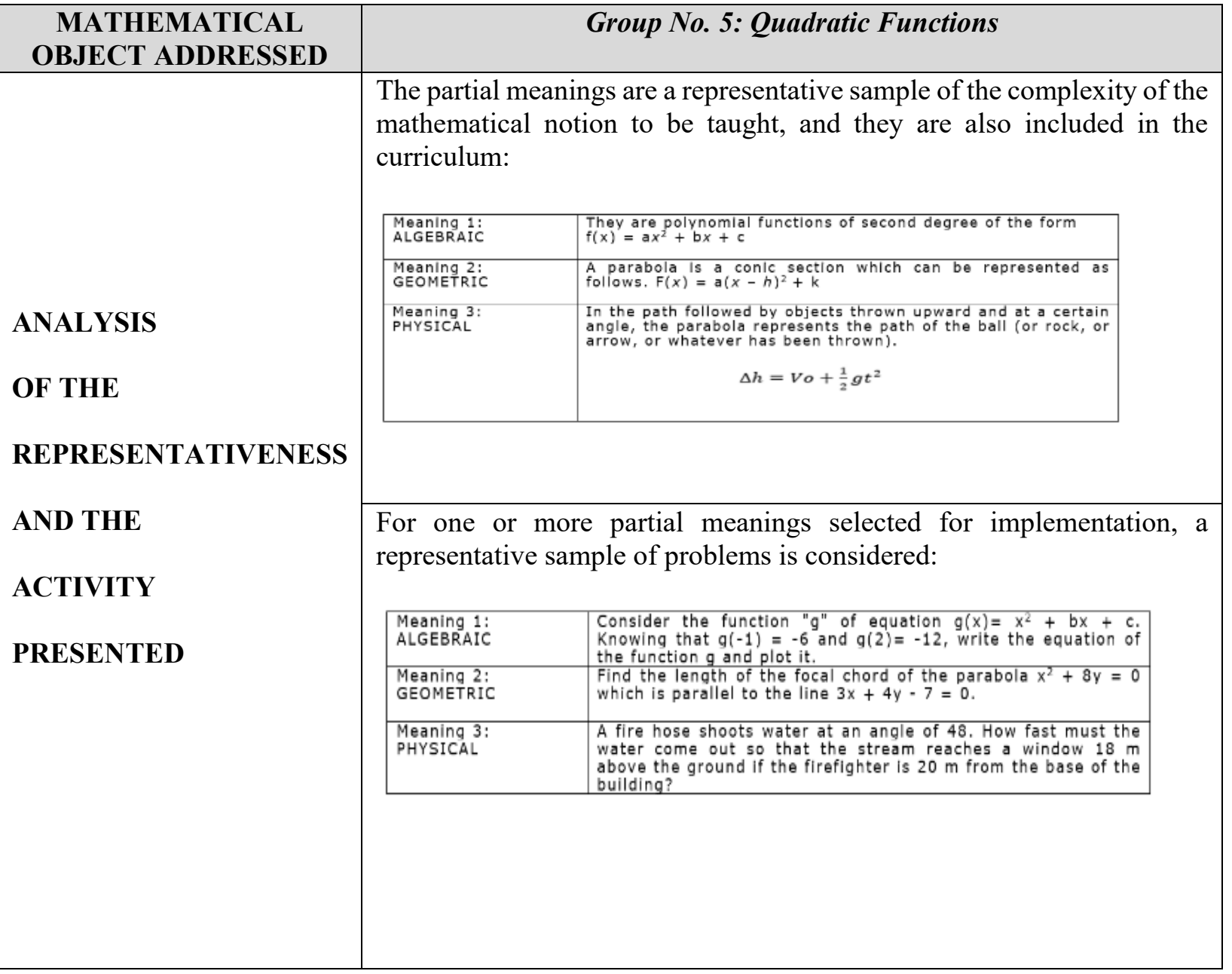




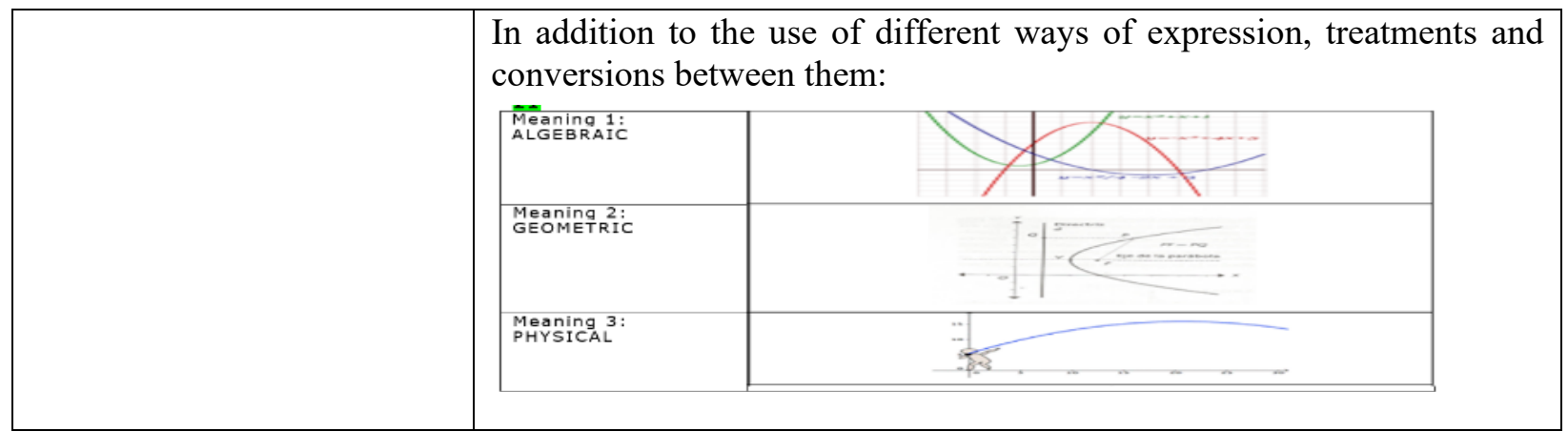

Source: developed by the authors.

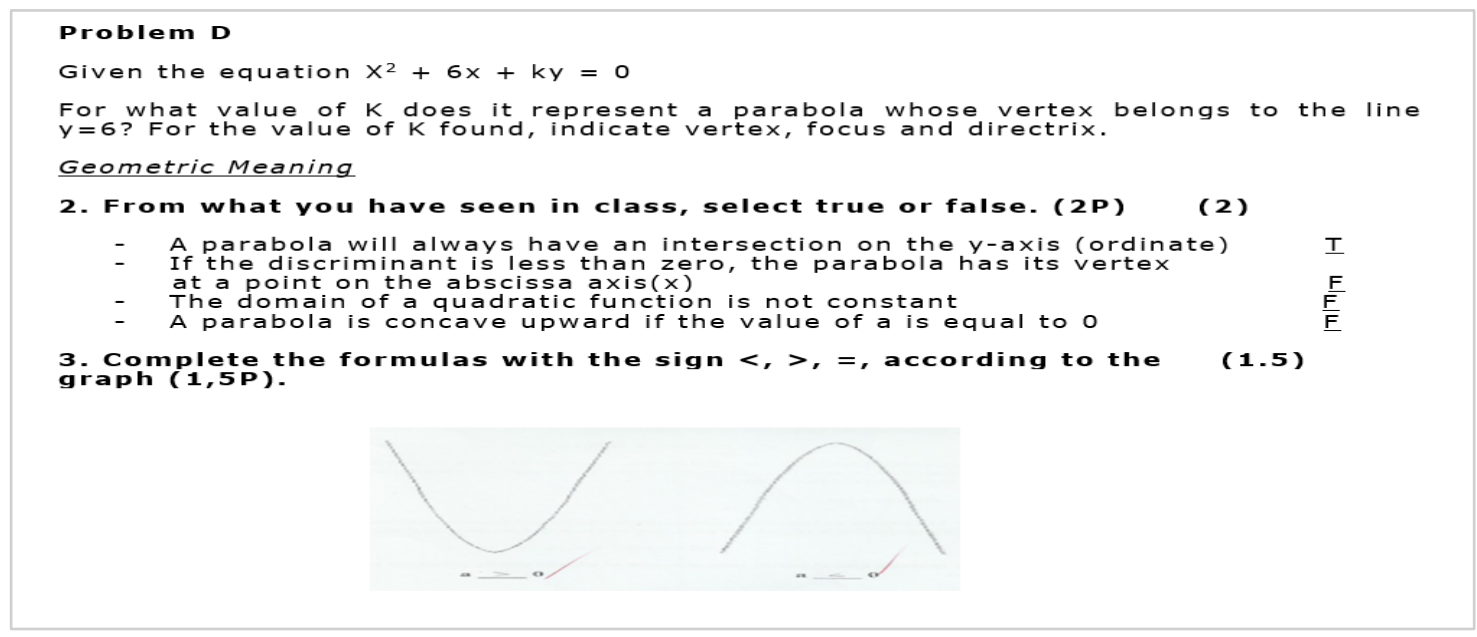

Analyzing the activity performed by group No. 5, it can be observed that representativeness is taken into account through algebraic, geometric and physical meanings; and in the evaluation applied to 14 classmates, eight have an "excellent performance", four have a "normal performance" and only two, a "low performance" (as indicated by the presenters).

\section{FIGURE 5 TEST APPLIED BY GROUP NO. 5}

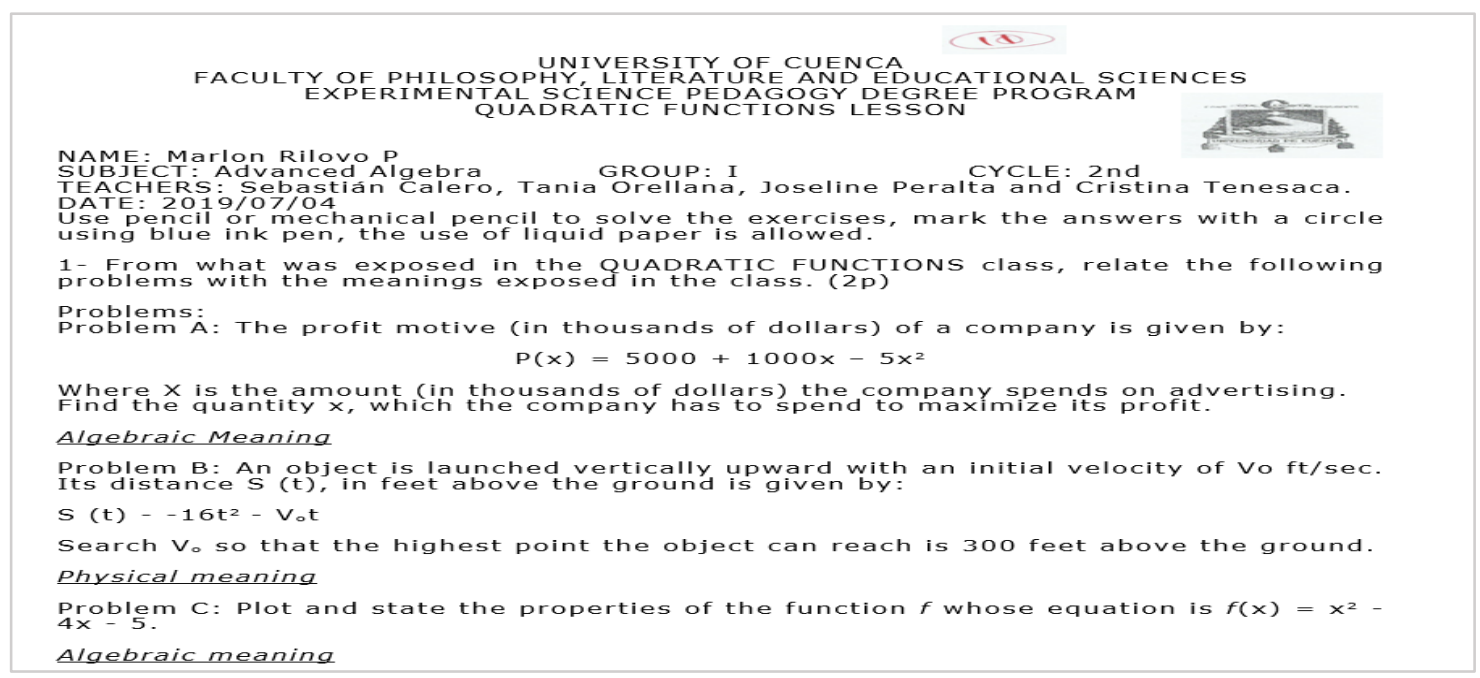

Source: Developed by the Authors 


\title{
RESULTS DISCUSSION
}

Of the 19 students who participated in this activity, the majority agreed that mathematical objects can be approached from their different meanings, as shown in Figure 6:

\section{FIGURE 6 \\ STUDENT'S RESPONSES}

\begin{abstract}
6. Do you think that mathematical objects can be represented in different ways?

( 2 P)

Explain why. Yes, because as we explained above there are several ways to explain these objects in such a way that the information is provided in a variety of ways so that it reaches all our students.

8. Nowadays it is recommended to develop mathematical competencies; that is, students are expected to be able to solve different problems by applying the content that has been taught. Do you think that if we had explained only one of the proposed meanings, about arithmetic mean, the student would have been able to solve all the proposed problems? If your answer is no, what do you suggest in order to solve all the problems? (4P)

No, because some may understand and others may not, so it is suggested to address various meanings with known words for greater student comprehension. In addition, all the characteristics of the topic should be gathered in order to make the subject matter even better known.
\end{abstract}

Source: Developed by the Authors

Once these proposals of multiple meanings of mathematical objects and their respective evaluations have been concluded and shared, the perception of these future teachers is presented through the conclusions and recommendations of each of the groups:

TABLE 7

CONCLUSIONS AND RECOMMENDATIONS ISSUED BY THE STUDENTS PARTICIPATING IN THE PROPOSAL

\begin{tabular}{|l|l|}
\hline $\begin{array}{c}\text { WORKING } \\
\text { GROUPS }\end{array}$ & \multicolumn{1}{c|}{ Conclusions and recommendations } \\
\hline Group & $\begin{array}{l}\text { The results of this work have been successful since a single topic can be broken down } \\
\text { into smaller but no less important ones, that means, the topic is related to more branches } \\
\text { of mathematics which can be useful to relate it and that students integrate the meanings, } \\
\text { it is a very good proposal since students know more than a single meaning and they can } \\
\text { work in their own way, so that they can reach the same result without having applied } \\
\text { the same process, I would recommend to continue working with this type of proposals } \\
\text { since the results are good. }\end{array}$ \\
\hline Group & $\begin{array}{l}\text { Upon observing and analyzing the results of the work, it is concluded that the } \\
\text { application of this methodology within the classroom has been successful, since most } \\
\text { of our classmates obtained "correct" in the majority of the problems posed. It can be } \\
\text { stated that, in order to achieve meaningful learning with successful learning } \\
\text { achievements, it is necessary to introduce different meanings of mathematical objects, } \\
\text { since each student has his or her own learning and assimilation style. Concluding the } \\
\text { peer review, it is clear that each one adopted the best meaning in accordance with the } \\
\text { context of the problem, in order to facilitate the resolution of the problems. } \\
\text { In our opinion, we consider that the use of didactic material for the explanation of the } \\
\text { different meanings would be a good way to achieve meaningful learning in students. }\end{array}$ \\
\hline
\end{tabular}




\begin{tabular}{|c|c|}
\hline & $\begin{array}{l}\text { From our point of view, we think that applying exercises that illustrate each of the } \\
\text { meanings of mathematical objects would help to achieve successful results. Before } \\
\text { concluding, we would like to suggest a last recommendation based on the results and } \\
\text { conclusions reached after the evaluation and research, so we can say that, if teachers } \\
\text { apply this methodology in the classroom, they will achieve significant learning in } \\
\text { students, since each one will choose the meaning that best suits their understanding or } \\
\text { the context of the problem, obtaining excellent results. }\end{array}$ \\
\hline $\begin{array}{l}\text { Group } \\
\text { No. } 3\end{array}$ & $\begin{array}{l}\text { As a conclusion, we can apply this proposal since the subject is one of the most basic } \\
\text { within algebra and it is also the basis for the next years. In the same way, students can } \\
\text { develop their capabilities. In addition, it is a didactic proposal in which students can } \\
\text { interact with the teacher and their classmates, thus keeping a satisfactory environment. } \\
\text { Furthermore, we can use didactic materials and apply learning methodologies such as } \\
\text { constructivism and technology by using applications such as GeoGebra. However, } \\
\text { many times there will be conditions in which students, even though they know the } \\
\text { required mathematical meanings, tend to confuse some things such as the case of } \\
\text { trigonometric identities or factorization. }\end{array}$ \\
\hline $\begin{array}{l}\text { Group } \\
\text { No. } 4\end{array}$ & $\begin{array}{l}\text { Fractions are indispensable to our lives, whether in a job or in educational institutions. } \\
\text { In order to apply them, it is necessary to have an understanding of the concept. It is very } \\
\text { important to clarify the meanings of mathematical objects in order to facilitate the } \\
\text { learning of mathematics. The use of didactic material is essential for facilitating } \\
\text { understanding in the teaching-learning process; it also helps teachers and future teachers } \\
\text { who experience this way of working to reinforce the contents they already have about } \\
\text { fractions and to significantly build methodological strategies that will be useful for } \\
\text { conceptualizing the notion of fractions. As a conclusion, when applying the test, the } \\
\text { results we obtained were very positive, since the great majority of the students know } \\
\text { how to recognize and interpret mathematical meanings, so we can say that there was } \\
\text { significant learning. } \\
\text { Students should know the properties to be applied when solving operations with } \\
\text { fractions. Making the meanings of different mathematical objects known is a strategy } \\
\text { that can really contribute a lot to teaching practice and facilitate student learning. }\end{array}$ \\
\hline $\begin{array}{l}\text { Group } \\
\text { No. } 5\end{array}$ & $\begin{array}{l}\text { As a consequence of the constant technological evolution, nowadays there are different } \\
\text { sources in which we can find a lot of information related to the topic we need, either } \\
\text { through web pages or virtual libraries, which are very useful tools for both students and } \\
\text { teachers in order to keep up with the constant innovation of knowledge. There are } \\
\text { different ways to teach a certain subject either in the area of mathematics or physics, } \\
\text { mathematical objects have several meanings which are very helpful for teachers because } \\
\text { they can choose the meaning that best suits the needs of students and the topic that needs } \\
\text { to be explained depending on the subject they are teaching, so they can explain correctly } \\
\text { and can reach their students so that they learn in a meaningful way and do not have any } \\
\text { complications in higher courses. In order to confirm that the students are learning, the } \\
\text { teacher must apply some periodic evaluations on the topics that have been previously } \\
\text { explained, to which a grade is assigned to reflect the level of knowledge that the student } \\
\text { has about the subject. } \\
\text { We should not abuse the use of technology because it can be a great distraction, for this } \\
\text { reason there are students who use it excessively and many times they do not use it for } \\
\text { academic purposes. Both teachers and students should make sure that the sources from } \\
\text { which they obtain information are reliable, since there are several sources in which the } \\
\text { information is false. }\end{array}$ \\
\hline
\end{tabular}

Source: developed by the authors. 
Therefore, it is concluded that, after this instructional process, the participants had the perception that it is important to take into account the complexity of the mathematical objects to be taught in the teaching practice, in order to achieve significant learning in the students of Basic General Education and High School. They also state that the different meanings should be presented gradually.

It is also highlighted in the responses that the participants showed different meanings of mathematical objects, both intra, as well as extra-mathematical, such is the case of group No. 5 that considered the meanings within Physics that also corresponds to their professional training (Teaching in Mathematics and Physics); which can be considered as evidence of their ability to work, not only in intra-mathematical contexts, but also in extra-mathematical contexts, i.e. as a connection that can be given between mathematics and the real world (Font, et al, 2017).

\section{CONCLUSIONS AND IMPLICATIONS}

In different training processes for mathematics teachers in Spain, Mexico, Brazil, Ecuador, Chile, Panama, Costa Rica, Venezuela and Argentina, a series of investigations have been carried out to investigate the use of the didactic suitability criteria construct as a tool to organize the teacher's reflection on his/her practice, when this reflection is focused on the evaluation and improvement of the practice, with the objective of developing in teachers the subcompetence of analysis of the didactic suitability of an instructional process. These investigations have revealed the following aspects: 1) although the teaching of the components and indicators of the didactic suitability criteria are not explicitly incorporated, some of them, and in particular the component $<<$ representative sample of the mathematical object complexity $>>$, are implicitly present when teachers or future teachers make evaluations of didactic proposals (their own or others') (Breda, 2020; Breda and Lima, 2016; Breda, Pino-Fan and Font, 2017). 2) Incorporating the component $<<$ representative sample of the mathematical object complexity $>>$ to assess the epistemic suitability of a teaching and learning process, is not an easy task, neither for trainers nor for their students (future teachers or in-service teachers), but it can be taught as part of the teacher training process. In these training devices, emphasis is placed on the need to carry out a preliminary study focused on the reconstruction of a global meaning of the mathematical object to be taught in order to be aware of its complexity.

According to the above mentioned research, as a result of the experience, students in teacher training are aware that, in order to improve the learning of mathematics, it is necessary to take into consideration the complexity of mathematical objects, understood as the different ways of understanding the meanings and their application in the resolution of problems. In addition, analyzing what the participants worked on in this proposal, it gives us the idea that they could progress in their reflection and deepen in the complexity articulation associated to the mathematical object as a previous and necessary step to advance to a unitary vision of the mathematical object (Rondero and Font, 2015).

\section{ACKNOWLEDGMENTS}

This work was supported by the research projects in teacher education: PGC2018-098603-B-I00 (MCIU/AEI/FEDER, UE), REDICE18-2000 (ICE- UB).

Translated \& edited by American Publishing Services (https://americanpublishingservices.com/). 


\section{REFERENCES}

Balcaza, T., Contreras, A., \& Font, V. (2017). Análisis de Libros de Texto sobre la Optimización en el Bachillerato. Bolema, 31(59), 1061-1081.

Breda, A. (2020). Características del análisis didáctico realizado por profesores para justificar la mejora en la enseñanza de las matemáticas. Bolema, 34(66), 69-88. doi: 10.1590/1980-4415v34n66a04

Breda, A., \& Lima, V.M.R. (2016). Estudio de caso sobre el análisis didáctico realizado en un trabajo final de un máster para profesores de matemáticas en servicio. REDIMAT - Journal of Research in Mathematics Education, 5(1), 74-10. doi: 10.4471/redimat.2016.1955

Breda, A., Pino-Fan, L.R., \& Font, V. (2017). Meta Didactic-Mathematical Knowledge of Teachers: Criteria for The Reflection and Assessment on Teaching Practice. EURASIA Journal of Mathematics, Science and Technology Education, 13, 1893-1918. doi:10.12973/eurasia.2017.01207a

Burgos, M., Castillo, M.J., Beltrán-Pellicer, P., \& Godino, J.D. (2020). Análisis didáctico de una lección sobre proporcionalidad en un libro de texto de primaria con herramientas del enfoque ontosemiótico. Bolema, 34(66), 40-68. https://doi.org/10.1590/1980-4415v34n66a03

Contreras, A., García, M., \& Font, V. (2012). Análisis de un Proceso de Estudio sobre la Enseñanza del Límite de una Función. Bolema, 26(42B), 667-690.

Font, V. (2007). Comprensión y contexto: una mirada desde la didáctica de las matemáticas. La Gaceta de la Real Sociedad Matemática Española, 10(2), 419-434.

Font, V., Breda, A., \& Seckel, M.J. (2017). Algunas implicaciones didácticas derivadas de la complejidad de los objetos matemáticos cuando estos se aplican a distintos contextos. Revista Brasileira de Ensino de Ciência e Tecnologia, 10(2), 1-23. doi: 10.3895/rbect.v10n2.5981

Font, V., Godino, J. D., \& Gallardo, J. (2013). The emergence of objects from mathematical practices. Educational Studies in Mathematics, 82, 97-124.

Font, V., Planas, N., \& Godino, J.D. (2010). Modelo para el análisis didáctico en educación matemática. Infancia y Aprendizaje, 33(1), 89-105.

Giacomone, B., Godino, J.D., \& Beltrán-Pellicer, P. (2018). Developing the prospective mathematics teachers' didactical suitability analysis competence. Educação e Pesquisa, 44, e172011.

Godino, J.D., Batanero, C., \& Font, V. (2007). The onto-semiotic approach to research in mathematics education. ZDM- The International Journal of Mathematics Education, 39(1), 127-135.

Godino, J.D., Batanero, C., \& Font, V. (2019). The Onto-semiotic Approach: Implications for the prescriptive character of didactics. For the Learning of Mathematics, 39(1), 37-42.

Godino, J.D., Beltrán-Pellicer, P., Burgos, M., \& Giacomone, B. (2017). Significados pragmáticos y configuraciones ontosemióticas en el estudio de la proporcionalidad. In J.M. Contreras, P. Arteaga, G.R. Cañadas, M.M. Gea, B. Giacomone, \& M.M. López-Martín (Eds.), Actas del Segundo Congreso International Virtual sobre el Enfoque Ontosemiótico del Conocimiento y la Instrucción Matemáticos. Retrieved from enfoqueontosemiotico.ugr.es/civeos.html

Godino, J.D., Font, V., Wilhelmi, M.R., \& Arrieche, M. (2009) ¿Alguien sabe qué es el número? Unión, $19,34-46$.

Godino, J.D., Giacomone, B., Batanero, C., \& Font, V. (2017). Enfoque ontosemiótico de los conocimientos y competencias del profesor de matemáticas. Boletim de Educação Matemática, 31(57), 90-113.

Gordillo, W., \& Pino-Fan, L. (2016). Una propuesta de reconstrucción del significado holístico de la antiderivada. Bolema, 30(55), 535-558.

Gordillo, W., Pino-Fan, L.R., Font, V., \& Ponce, J.C. (2018). Algunas tareas para evaluar la comprensión sobre el objeto matemático antiderivada. Academia y Virtualidad, 11(2).

Monje, Y., Seckel, M.J., \& Breda, A. (2018). Tratamiento de la Inecuación en el Currículum y Textos Escolares Chilenos. Bolema, 32(61), 480-502.

Pino-Fan, L., Castro, W.F., Godino, J.D., \& Font, V. (2013). Idoneidad epistémica del significado de la derivada en el currículo de bachillerato. Paradigma, 34(2), 123-150. 
Pino-Fan, L., Godino, J.D., \& Font, V. (2011). Faceta epistémica del conocimiento didáctico-matemático sobre la derivada. Educação Matemática Pesquisa, 13(1), 141-178.

Pino-Fan, L., Godino, J.D., \& Font, V. (2018). Assessing key epistemic features of didactic-mathematical knowledge of prospective teachers: The case of the derivative. Journal of Mathematics Teacher Education, 21(1), 63-94.

Pino-Fan, L.R., Font, V., Gordillo, W., Larios, V., \& Breda, A. (2018). Analysis of the meanings of the antiderivative used by students of the first engineering courses. International Journal of Science and Mathematics Education, 16(6), 1091-1113. Doi: 10.1007/s10763-017-9826-2

Rondero, C., \& Font, V. (2015). Articulación de la complejidad matemática de la media aritmética. Enseñanza de las Ciencias: Revista de Investigación y Experiencias Didácticas, 33(2), 29-49. 